\begin{tabular}{|c|c|c|c|c|c|c|c|c|}
\hline 우 & $\begin{array}{l}11-15 \mathrm{~g} \\
16-20 \mathrm{~g} \\
21-25 \mathrm{~g} \\
26-30 \mathrm{~g} \\
31-35 \mathrm{~g}\end{array}$ & $\begin{array}{l}3 \\
5 \\
1 \\
2 \\
3\end{array}$ & $\begin{array}{r}57-73 \\
61-66 \\
66 \\
74-77 \\
56-74\end{array}$ & $\begin{array}{l}62 \\
63 \\
66 \\
76 \\
64\end{array}$ & $\begin{array}{r}6^{\prime} 57^{\prime \prime}-20^{\prime} 50^{\prime \prime} \\
10^{\prime} 00-15^{\prime} 05^{\prime \prime} \\
15^{\prime \prime} 25^{\prime \prime} \\
12^{\prime \prime} 35^{\prime \prime}-16^{\prime} 00 \\
13^{\prime} 23^{\prime \prime}-16^{\prime} 45^{\prime \prime}\end{array}$ & $\begin{array}{l}15^{\prime} 12^{\prime \prime} \\
129^{\prime \prime} \\
15^{\prime} 25^{\prime \prime} \\
14^{\prime} 18^{\prime \prime} \\
15^{\prime} 00\end{array}$ & $\begin{array}{rr}1.92-5.75 & 3.29 \\
2.63-4.00 & 3.17 \\
2.57 & 2.57 \\
2.50-3.16 & 2.83 \\
2.37-2.98 & 2.68\end{array}$ & $\begin{array}{r}20.0-23.0^{\circ} \\
20.7-23.0^{\circ} \\
20.7^{\circ} \\
23.0-25.5^{\circ} \\
20.7-23.0^{\circ}\end{array}$ \\
\hline 摘要 & $11-35 g$ & 14 & $56-77$ & 61 & $6^{\prime} 57^{\prime \prime}-20^{\prime} 50^{\prime \prime}$ & $14^{\prime} 15^{\prime \prime}$ & $1.92-5.753 .00$ & $20.0-25.5^{\circ}$ \\
\hline 總括 & $11-35 g$ & 42 & $41-77$ & 61 & $6^{\prime} 57^{\prime \prime}-30^{\prime} 00$ & $15^{\prime} 27^{\prime \prime}$ & $1.70-5,75 \quad 2.83$ & $20.0-25.5$ \\
\hline
\end{tabular}

ヂキタリス粗末 F4.5 (藤罯 $16-10-28$ )

\begin{tabular}{|c|c|c|c|c|c|c|c|c|c|}
\hline 今े & $\begin{array}{l}14-15 \mathrm{~g} \\
16-20 \mathrm{~g} \\
21-25 \mathrm{~g} \\
26-30 \mathrm{~g} \\
30-35 \mathrm{~g} \\
36-37 \mathrm{~g}\end{array}$ & $\begin{array}{l}3 \\
8 \\
5 \\
3 \\
0 \\
1\end{array}$ & $\begin{array}{r}49-75 \\
60-90 \\
55-78 \\
43-72 \\
\\
57\end{array}$ & $\begin{array}{r}61 \\
75 \\
66 \\
61 \\
0 \\
57\end{array}$ & $\begin{array}{r}11^{\prime} 22^{\prime \prime}-27^{\prime} 00 \\
85^{\prime \prime}-26^{\prime} 53^{\prime \prime} \\
8^{\prime} 18^{\prime \prime}-14^{\prime} 40^{\prime \prime} \\
9^{\prime} 57^{\prime \prime}-14^{\prime} 10^{\prime \prime} \\
24^{\prime} 47^{\prime \prime}\end{array}$ & $\begin{array}{c}18^{\prime} 32^{\prime \prime} \\
14^{\prime} 24^{\prime \prime} \\
12^{\prime} 49^{\prime \prime} \\
12^{\prime} 10^{\prime \prime} \\
0 \\
24^{\prime} 47^{\prime \prime}\end{array}$ & $\begin{array}{r}1.48-3.52 \\
1.49-4.56 \\
2.71-4.77 \\
2.68-4.03 \\
1.79\end{array}$ & $\begin{array}{r}2.44 \\
3.07 \\
3.30 \\
3.31 \\
0 \\
1.79\end{array}$ & $\begin{array}{r}24.0-26.5^{\circ} \\
23.5-26.5^{\circ} \\
23.5-24.5^{\circ} \\
24.0-26.5^{\circ} \\
0 \\
24.5^{\circ}\end{array}$ \\
\hline 㨄要 & $14-37 \mathrm{~g}$ & 20 & $42-90$ & 64 & $8^{\prime} 18^{\prime \prime}-27^{\prime} 00$ & $14^{\prime} 49^{\prime \prime}$ & $1.48-4.77$ & 3.00 & $23.5-26.5^{\circ}$ \\
\hline 우 & $\begin{array}{l}14-15 \mathrm{~g} \\
16-20 \mathrm{~g} \\
21-25 \mathrm{~g} \\
26-30 \mathrm{~g} \\
31-35 \mathrm{~g} \\
36-38 \mathrm{~g}\end{array}$ & $\begin{array}{l}1 \\
2 \\
7 \\
2 \\
0 \\
1\end{array}$ & $\begin{array}{r}38 \\
49-72 \\
60-90 \\
43-72 \\
-67\end{array}$ & $\begin{array}{r}38 \\
61 \\
73 \\
58 \\
0 \\
67\end{array}$ & $\begin{array}{r}21^{\prime} 20^{\prime \prime} \\
72^{\prime \prime}-23^{\prime} 30^{\prime \prime} \\
50^{\prime \prime}-14^{\prime} 30^{\prime \prime} \\
10^{\prime} 38^{\prime \prime}-16^{\prime} 45^{\prime \prime} \\
14^{\prime} 10^{\prime \prime}\end{array}$ & $\begin{array}{c}21^{\prime} 20^{\prime \prime} \\
15^{\prime} 31^{\prime \prime} \\
11^{\prime} 39^{\prime \prime} \\
13^{\prime} 42^{\prime \prime} \\
0 \\
14^{\prime} 10^{\prime \prime}\end{array}$ & $\begin{array}{r}1.88 \\
1.70-5.31 \\
2.71-6.88 \\
2.38-3,76 \\
2.83\end{array}$ & $\begin{array}{r}1.88 \\
3.51 \\
3.78 \\
3.07 \\
0 \\
2.83\end{array}$ & $\begin{array}{r}23.5^{\circ} \\
24.0-24.5^{\circ} \\
24.0-26.5^{\circ} \\
23.5-24.0^{\circ} \\
0 \\
24.5^{\circ}\end{array}$ \\
\hline 摘要 & $14-38 g$ & 13 & $38-90$ & 60 & $5^{\prime} 50^{\prime \prime}-23^{\prime} 30^{\prime \prime}$ & $14^{\prime} 16^{\prime \prime}$ & $1.70-6.88$ & 3.41 & $23.5-26.5^{\circ}$ \\
\hline 總括 & $14-38 g$ & 33 & $38-90$ & 62 & $5 ’ 50^{\prime \prime}-27^{\prime} 00$ & $14^{\prime} 17^{\prime \prime}$ & $1.48-6.88$ & 3.16 & $23.5-26.5^{\circ}$ \\
\hline
\end{tabular}

夏期よりは静止時間が概して延長してるるが, 30 分過ぎても搏動不止の例は逐に一例も之を見なかつた. 又 F4.

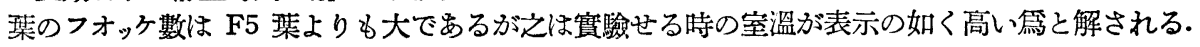

\title{
結
}

1）臺灣に座する水蛙及びプランシー蛙を用ひ 7-8 月に於てヂキタリス葉 [F5 (三共), F4.5 (藤濢)]のフオッケ數 の檢定を行つて，プランシー蛙使用の場合は標記よりは低值なるも略了近似の數を得た. 水蛙を使用の場合は實驗例 の約牛數は遥かに小なる効果數を示し他の牛數に於ては 30 分を經るも收縮性靜止に陷らなかつた. 又 10 一月の 實瞼に於ては室溫の降下に伴ひ静止時間は概して延長した。

2）静止時間は兩季節共かなり區々としてるる.

3）デキタリス葉に對する水蛙及プランシー蛙の抵抗力は水蛙の方がプランシー蛙より大である.

4) 臺北に於て栽培せるヂキタリス葉はプランシー蛙を用ひ，7-8 月に於て檢定せるに施肥の如何を問はず皆比較 的大なるフオッケ數を示した.

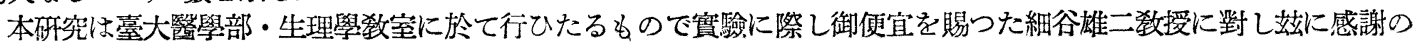
意を表する.

(昭和 18 年 2 月 1 日)

\section{7. 田中欽ニ：防己科アルカロイド研究（第六十八報）「ッスノハカッ゙ラ」} のアルカロイドェピステファニンの棈造䂗究（其九）

$$
\text { [附 } \varphi \text {-エピステファニンの構造論] }
$$

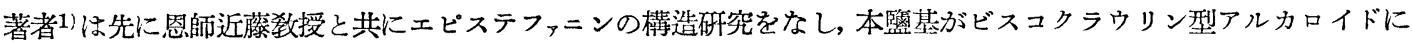
屬し, 分子式 $\mathrm{C}_{37} \mathrm{H}_{38(36)} \mathrm{N}_{2} \mathrm{O}_{\hat{o}}$ を與へ，更にその還元體は互に diastereomer の關係にあるヒドロエピステファニンーA 及-Bよりなり．前者はホフアン分解に附してデ・N・メチルオキシアカンチンを得た事からヒドロエピステファニンに 次の四式 (I-VI) 中の一に一致し, 且 A の不齊の中心は $(+,+)$ B の不齊の中心は (+,一) なる事を推論した.

1) 近藤, 田中：本誌 $63,267,273$ (1943). 


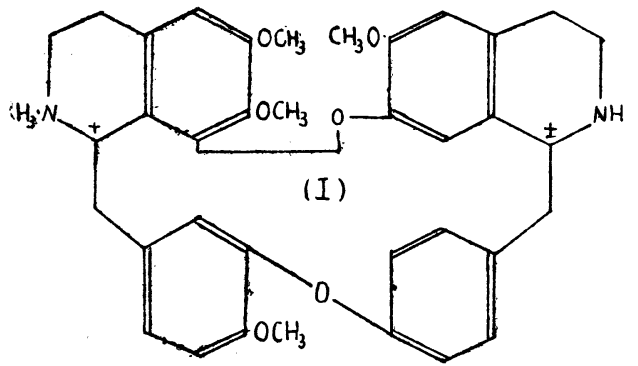

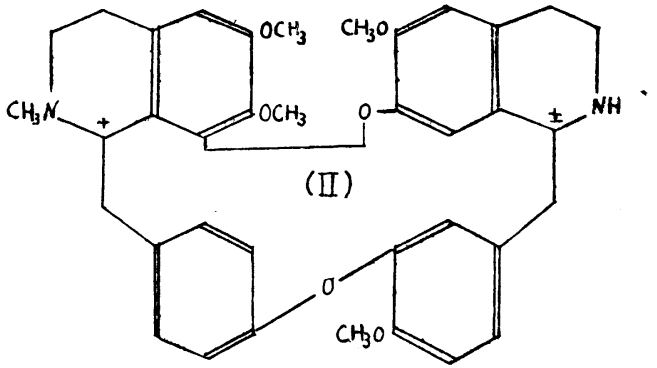

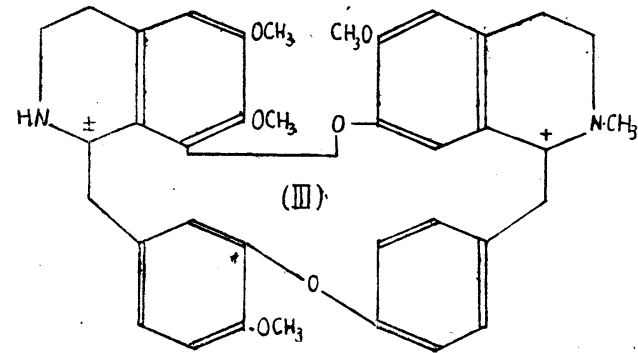

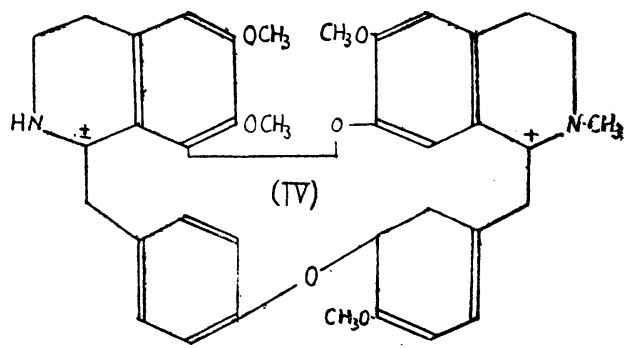

著者はヒドロエピステファニンに對する此の推定構造式を更に確證する浔, 今包オキシアカンチンと併行して兩者の エムデ分解を比較する事にした．試料オキシアカンチンは小檗2)より近藤富田兩敎授の報告3)に從つて抽出したるの である.

オキシアカンチンのエムデ分解は既に Späth が行ひ, ヒドロメチンは結晶性に得られなかつたが, そのヨードメチ

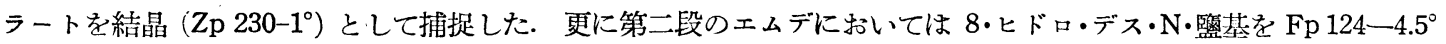
の結晶として得て居る.

抑々ハスノハカッ゙ラのアルカロイドの含量は其探集地域及探集時期によつ極めて變動が大で，昨年末鹿兒島縣南部 地方で探集され目下乙吅研究所所員渡邊敏雄氏の下に抽出中のものはェピステファニンが含有せず. それに對して $\varphi$. エピステファニンはかつてなき良得量で得られつ〉ある. 幸にも最近近藤呚授 ${ }^{5}$ は協力者野副氏と $\varphi$ ・ビステファニ ンをヂアゾメタンでメチル化してェピステファニンを得る事が報告されて居るので, 著者は渡邊氏より分與された $\varphi$. エピステファニンにヂアゾメタンを作用してェピステファニンとなし, 更に前報1に從つてェピステファニンを還元した

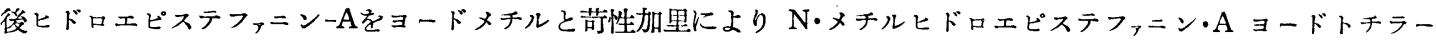
トを製してェムデ分解の原料とした.

本ヨードメチラートを Späth の報告に依つて新製㲯化銀でクロールメチラートとなし，5\%ナトリウムアマルガ ムでェムデ分解に附し, 實驗の部に記述する如く處理すると, ヒドロメチンは Fp $110-2^{\circ}$ の針狀結晶 $\left(\mathrm{C}_{40} \mathrm{H}_{50} \mathrm{~N}_{2} \mathrm{O}_{6}\right)$ となる. 本品は多少吸濕性である. 又そのヨードメチラートは $\mathrm{Zp} 240-2^{\circ}$ の白色稜杜狀結晶 $\left(\mathrm{C}_{40} \mathrm{H}_{50} \mathrm{~N}_{2} \mathrm{O}_{6} \cdot 2 \mathrm{CH}_{3} \mathrm{~J}\right.$. $\left.4 \mathrm{H}_{2} \mathrm{O}\right)$ である. 一方オキシアカンチンよりも同樣に處理し, Späth がかつて得なかつたヒドロメチンを針狀結晶 $(\mathrm{Fp}$ 110 - $\left.2^{\circ}\right)$ として得られ，そのヨードメチラートも (Zp 240-2º $)$ の結晶として得た. ヒドロメチン並にヨードメチラ 一トは混融の結果は全く融點の降下を認めず同一物なる事を知つた. 向兩者のヒドロメチン再結晶母液をヨードメチ ラートとなす時は明に混合物であつて, 分劃結晶の結果は兩者共に上記メタノールに䧼溶のヨードメチラート $(\mathrm{Zp}$ $\left.240-1^{\circ}\right)$ 以外に易溶ヨードメチラート $\left(\mathrm{Zp} 210-1^{\circ}\right.$ 針狀結晶)を少量得た. 後者の組成は共に $\mathrm{C}_{40} \mathrm{H}_{50} \mathrm{~N}_{2} \mathrm{O}_{6} \cdot 2 \mathrm{C}_{3} \mathrm{HJ} \cdot$ $2 \frac{1}{2} \mathrm{H}_{2} \mathrm{O}$ を有し, ヒドロエピステフォニン並にオキシアカンチンの兩者より得た易溶性のヨードメチラートも又混融の

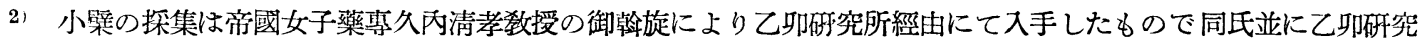
所に御禮申上げる.

3) 近藤, 富田 : 藥誌 50, 309 (1930).

4) Späth, Kolbe: B. 58, 2282 (1925).

5) 近藤, 野副：本年一月例會㢈上にて發表宁。 
結果全く降下を認めないのである． 前記の如く Späth はヒドロメチンのョードメチラートを Zp 230-1と記載し て居るが，氏の賔驗記錄から考へても同氏のヒドロメチンョードメチラートが混合物ならん事は容易に想像出來るの である，著者も亦ヨードメチラートの分劃結晶で中間に析出卞る結晶が Späth の記載に一致した. Zp 230一1の 混合結晶なる事を經驗した.

次にヒドロメチンョードメチラート $\left(\mathrm{Zp} 240-1^{\circ}\right)$ の第二次エムデ分解で $\mathrm{Fp} 124^{\circ}$ の針狀結晶 $\left(\mathrm{C}_{36} \mathrm{H}_{40} \mathrm{O}_{6}\right)$ を得た

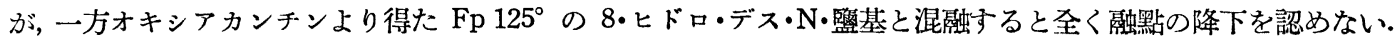

\begin{tabular}{|c|c|c|c|c|}
\hline & $\begin{array}{c}\text { ヒドロエピステ } \\
フ_{3}=ン\end{array}$ & \multirow{2}{*}{ 混融 } & \multicolumn{2}{|c|}{ オキシアカンチン } \\
\hline & 著 者 & & 者 & Späth \\
\hline ヒロドメチン & Fp $110-2^{\circ}$ & Fp $110-2^{\circ}$ & Fp $110-2^{\circ}$ & - \\
\hline ヒドロメチンョードメチラート(蜼溶) & Fp $240-2^{\circ}$ & Fp $240-2^{\circ}$ & $\mathrm{Zp} 240-2^{\circ}$ & $Z \mathrm{p} 230-1^{\circ}$ \\
\hline ヒドロメチンョードメチラート(易溶) & $Z \mathrm{p} 210-1^{\circ}$ & $\mathrm{Zp} 209-11^{\circ}$ & $Z \mathrm{p} 209-10^{\circ}$ & $\longrightarrow$ \\
\hline 八・ヒドロ・デス・N・鑒基 & $\mathrm{Fp} 124^{\circ}$ & $\mathrm{Fp} 124^{\circ}$ & $\mathrm{Fp} 125^{\circ}$ & Fp $124-4.5^{\prime}$ \\
\hline
\end{tabular}

先にヒドロエピステファニンのメトスルファ 一トをホフマン分解に附して得られるメチン 臨基 (Fp 109-10 ) をパラヂュウム炭を觸媒 として接觸還元を行ひ，ヒドロメチンとなし 直にヨードメチルを作用して得られるヒドロ メチンョードメチラートは Zp 242-3ㅇ の稜 杜狀結晶 $\left(\mathrm{C}_{40} \mathrm{H}_{50} \mathrm{~N}_{2} \mathrm{O}_{6} \cdot 2 \mathrm{CH}_{3} \mathrm{~J} \cdot 4 \mathrm{H}_{2} \mathrm{O}\right)$ となる 本品は先にェムデ分解によつて得たヒドロメ チンョードメチラート (Zp 240-2') と混融 すると全く融點の降下を示さず同一物である 事を知づた（本實興はェムデ分解を行ふ以 前に行つたのでヒドロメチンを結晶性に導く 事なく，直にヨードメチラートとなした爲遊 離鹽基における混融は行ふ事が出來なかつ た.）、此實驗によつて著者はヒドロエピステ ファニン・Aのエムデ分解で得たヒドロメチン が前報のホフマン分解に於いて得たメチン (Fp 109-10) を接觸還元して得たヒドロメ チンとが同一物なる事を認めたので，これに 依つてヒドロエピステフォニン・Aのホフマン 分解とエムデ分解とが同一開裂方向を取つた 事を示寸るのであり, 又メチン (Fp 109-10) の結晶水も確賽となつた。

メチルオキシアカンチンのホフマン分解で は Fp 1 1-2 2 のメチンを得, 本メチンがオ ゾン分解によつて $\alpha \cdot \alpha^{\prime}$-メチンである事は近 藤敎授 ${ }^{6)}$ 及 Bruchhausen7) によつて確定さ

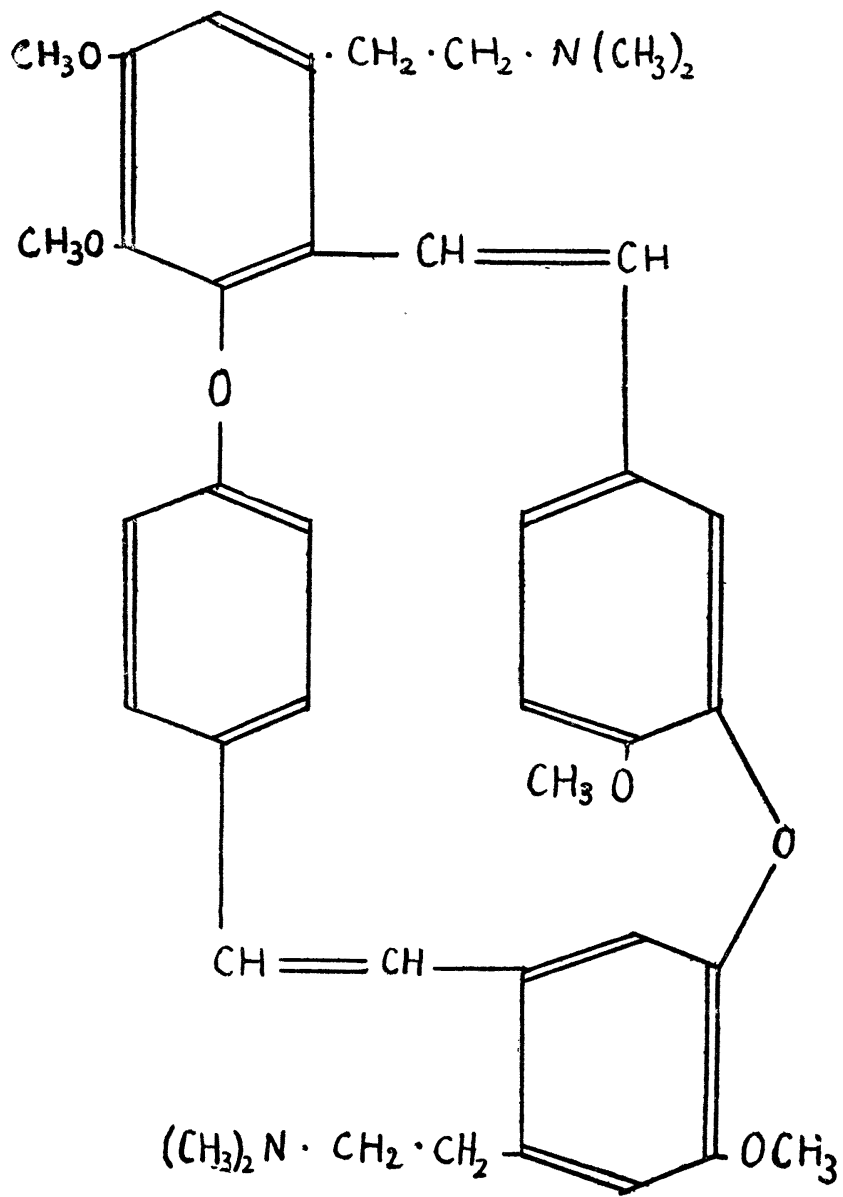
れた事實である. 一方オキシアカンチンと類似構造をもつと推定されるヒドロエピステフォニンのホフマン分解では

6) 近藤, 矢野: 藥誌 52827 (1932).

7) Bruchhausen Gerick: Arch 269115 (1931). 
Fp 109-10 のメチンしか得られなかつたが，その比旋光度及吸收曲線で $\alpha \cdot \alpha^{\prime}$ メメンならんと推論した.

King8 ${ }^{8}$ Tubocurarin $\sigma$ ホフマン分解に於いてそのメチンョードメチラートとして二種の不旋光性メチンを得で Stilben の cin-Trans 異性がその原因なる事を說いて居る. 併しオキシアカンチン及ヒドロエピステファニンの兩者 の場合にはいづれも一種の不旋光性メチンしか得られて居ないのであるから，King の䛃を考へるよりも寧ろメチン の元素分析が示す如く恐らく使用したアルカリの濃度の大なる差違の焦含水メチンがその原因と考へた方が合理的な 解稚である.

以上エムデ分解でヒドロエピステファニン・A がオキシアカンチンと全く同一分解成績體を得られ, 前述のホフマン 分解の結果と相俟つて先に提出したヒドロエピステファニンの構造式も確定的となつた. 從つてメチルオキシアカン チンと N・メチルヒドロエピステファニンの直接比較を必要としたが, 兩者のヨードメチラートの旋光度の測定を行つ て居ないから決定的とは云へないが, 兩者の混融の結果は融點の降下を認めなかつた事を附言して拉きたい、次に以 上の反隼の大要を圖示すれば次の如くである.

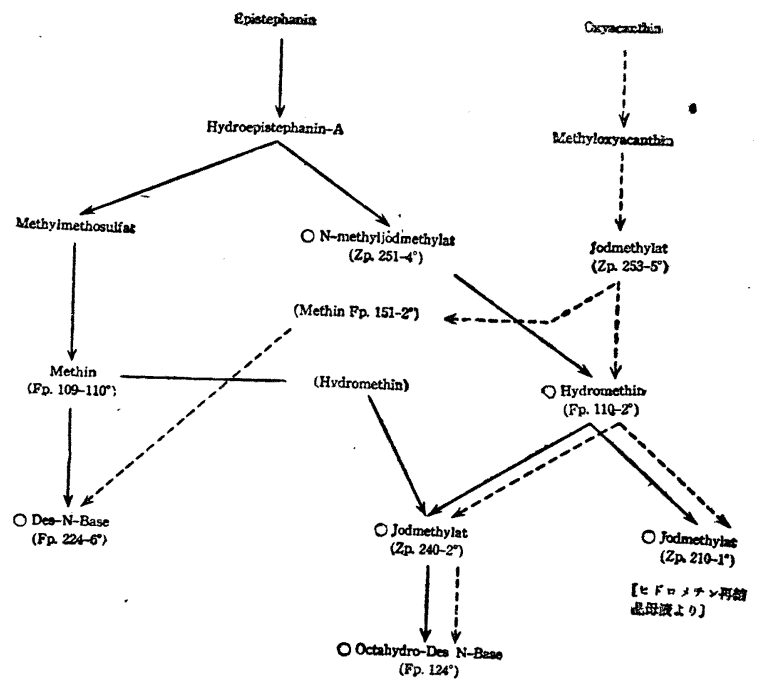

偖エピステファニンの棈造に閣しては前報において論議された如く，一方のイソヒノリンが稘正イソヒノリン核な りや, 叉は二・ヒドロイソヒノリン核なりやこの點のみが帖不明のま〉殘されて居る重要な問題である.この點に關 しては化學的方法によつて考究する時は多量の材料を必要とするから，研究材料少量でる以上何等か他の方法を撰 .ぶ必要にせまられた. 幸にも吸收スペクトルによる研究はこの點を解決するに役立ち. 最終的のェピステフォニンの棈
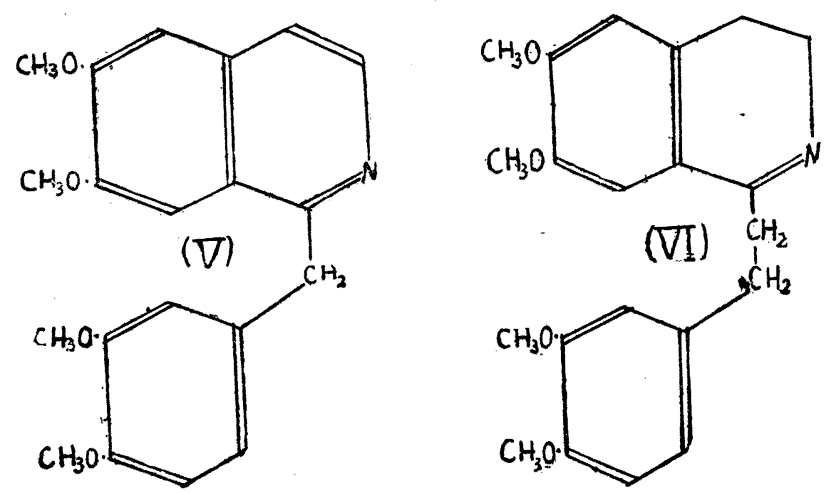

8) King: Soc. 19351381. 
造式を推定し得たのでこれについて述べる.

對象としてはイソヒノリン核を有するものにパパベリン $(\mathrm{V})$ を, 二ヒドロイソヒノリン核を有するものに菅澤敎授 より分與された 1-( $\beta-33^{\prime}, 4^{\prime}$-デメトオキシフェニルエチル)-6, 7-ヂメトオキシ-3, 4-デヒドロインヒノリン (VI) を撰 び, 三者の吸收曲線を比較したのである. 即ちエピステファニンの吸收に於いてはパパベリンに表はれる吸收 $(\log \varepsilon=$ $4.98 \mathrm{~m} u=238)$ がなく, 寧ろ後者の吸收に類似するのである. 畞ち後者の吸收 $\log \varepsilon=3.89 \mathrm{~m} u=310)$ もェピステ

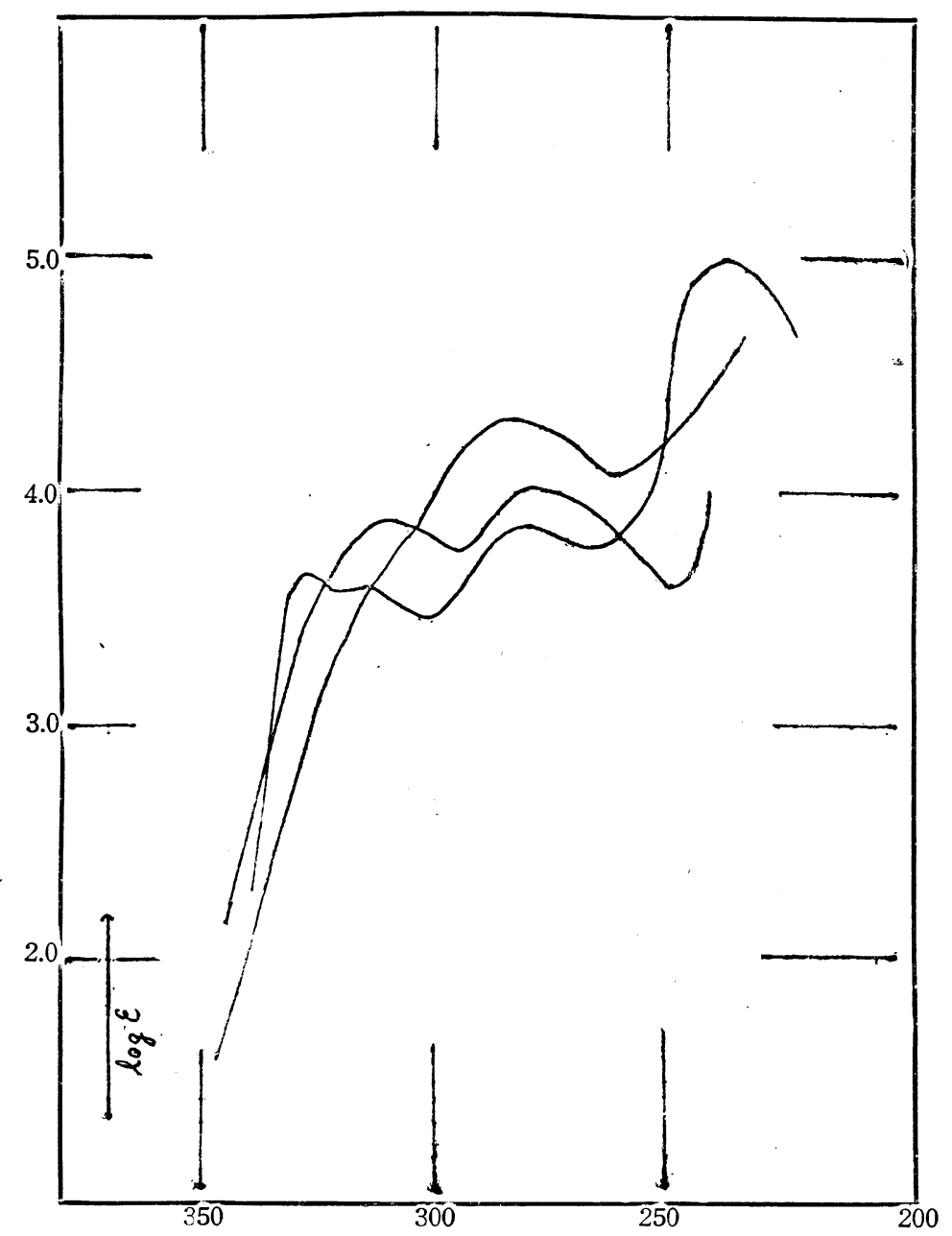

・ファニンの吸收曲線ではそれ自身の强き吸收の雹不明膫となつて居るが, 吸收 $(\log \varepsilon=3.70 \mathrm{~m} \mu=310)$ がそれに比適す るものと考へられる. 從つてェピステファニンの一方のインヒノリン核は覓正インヒノリン核にあらずして, 二・ヒド ロイソヒノリン核と考へた方が合理法である. 故にエピステファニンの䈐造は次の四式 (VII-X) 中の一にして $\mathrm{R}=$ $\mathrm{CH}_{3}$ の構造を以て示す事が出來る.

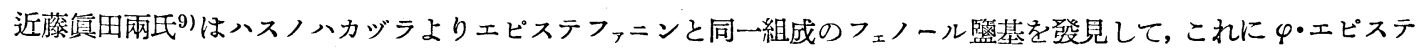
ファニンと品名されだ. 其後本監基をデメチル硫酸とアルカリでメチル化し, ヨード加里でメチルー $\varphi$ ・エピステファニ ンョードメチラートとなし, 本品がヂメチルモルフォテバインョードメチラートに對常體なる事を報告されて居る. 著 者は本研究の當初に怙いてェピステンィニンと同時に $\varphi$ ・エピステファニンの吸收曲線をむ作成したのであるが，兩者 の吸收曲線か極めてよく一致した事から兩者の棈造は類似性のある事を推定した.10 近藤野副兩氏は最近 $\varphi \cdot$ エピス

9) 近藤, 傎田：藥誌 51, 509 (1931).

10) 近藤野副の報文において兩者吸收曲線は報告されて居る. 


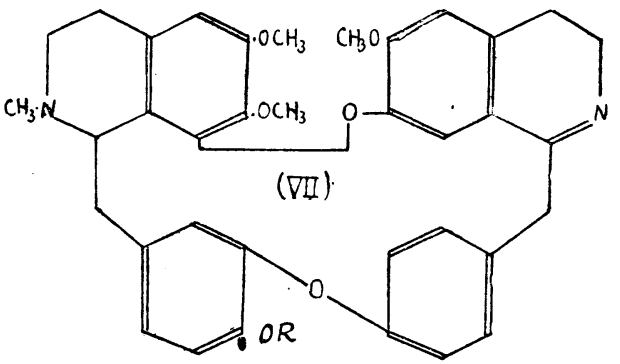

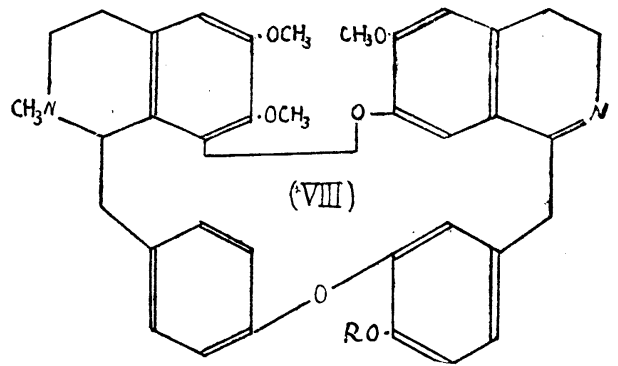
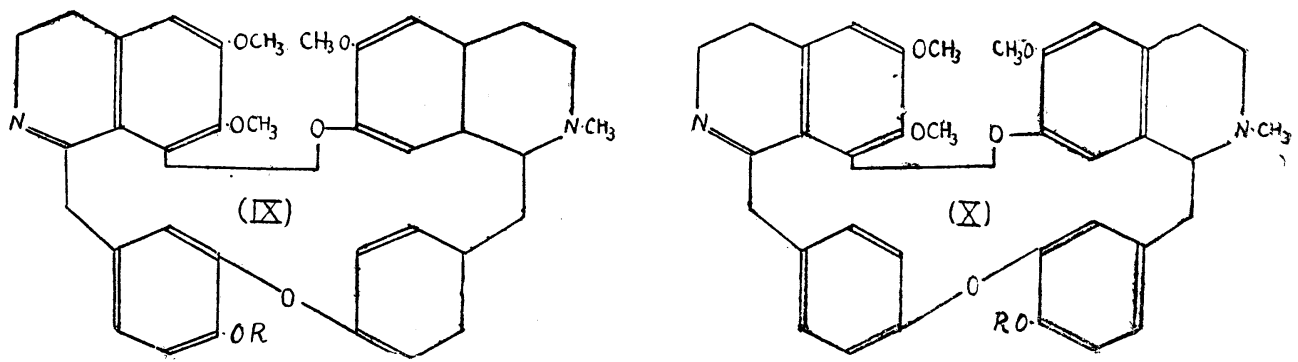

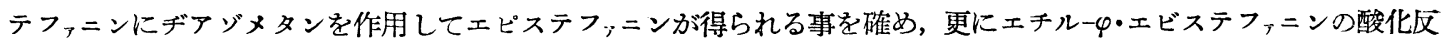
㤫で, $2 \cdot$ エトオキシヂフェニルエーテルヂカルボン酸 $\left(5,4^{\prime}\right)$ を得て, その一個のフェノール水酸基の位置も決定された

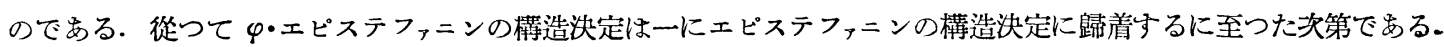
郎ち $\psi \cdot$ エピステファニンの構造は上の四式中の一に於いて $\mathrm{R}=\mathrm{H}$ なる样造をるつ事が明になつた.

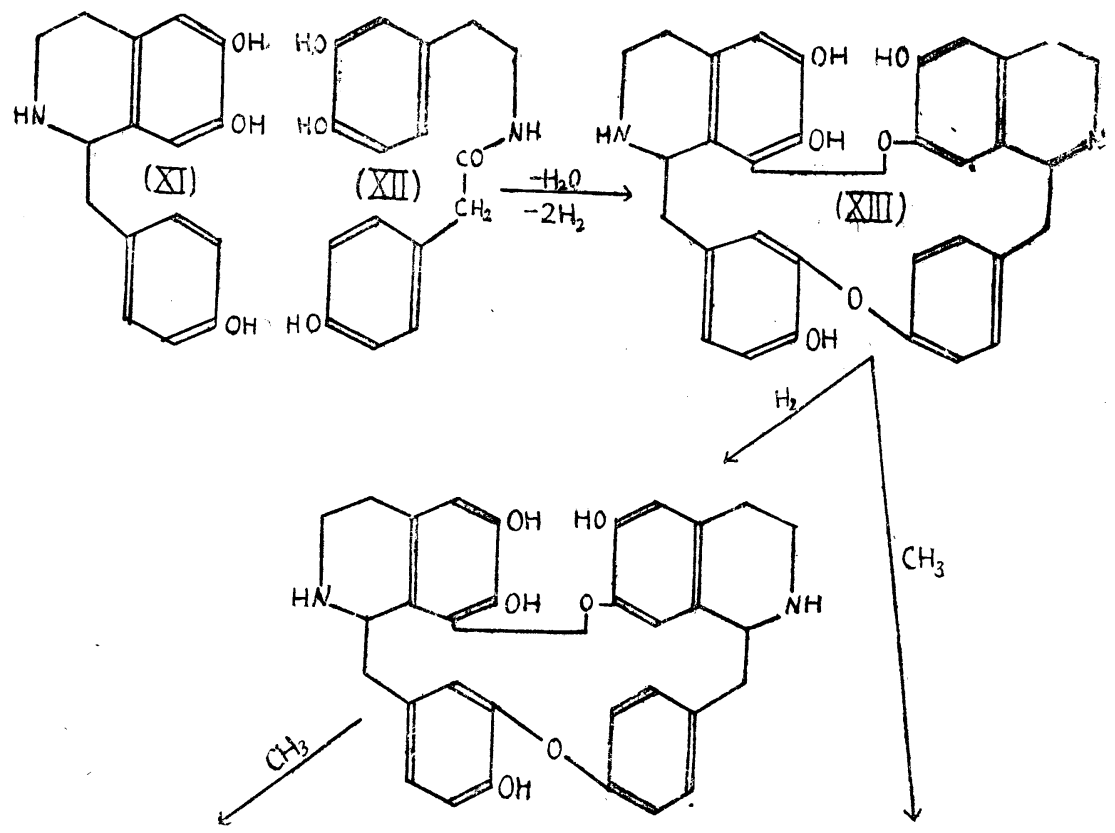

Oxyacantin

Epistephanin 
近藤富田兩敎授 ${ }^{11)}$ にピスコクラウリン型アルカロイドの Biogenese に關して一說を提出されたが, エピステファニ ンの権造決定は更にこの說に合致したよき一例をあげ得たものと云へる.

即ち植物體內でオキシアカンチンとその構造が一部變化したエピステフォニンとを發見した事は兩者の Biogenese を論ずるに當つて，其生成當初に执いて過程が同一と考へるのが合理的の樣に思はれる. 斯樣な考の下にオキシアカ ンチンとェピステファニンの生成を考へるならば, 先ノルコクラウリン $(\mathrm{XI})$ とその前身 $p$-Oxy-homobenzoyl-dioxyphenyläthylamin (XII) との脫水及脫水素反䭒に始り, ノルェピステフォニン (XIII) を中間體とし, エピステフォニン へはメチル化のみにて，オキシアカンチンへは還元反應及メチル化によつて生成するるのと考へれば, 少しの矛盾る なく且合理的に說明し得るのである.これを圖示すれば次の如くである.

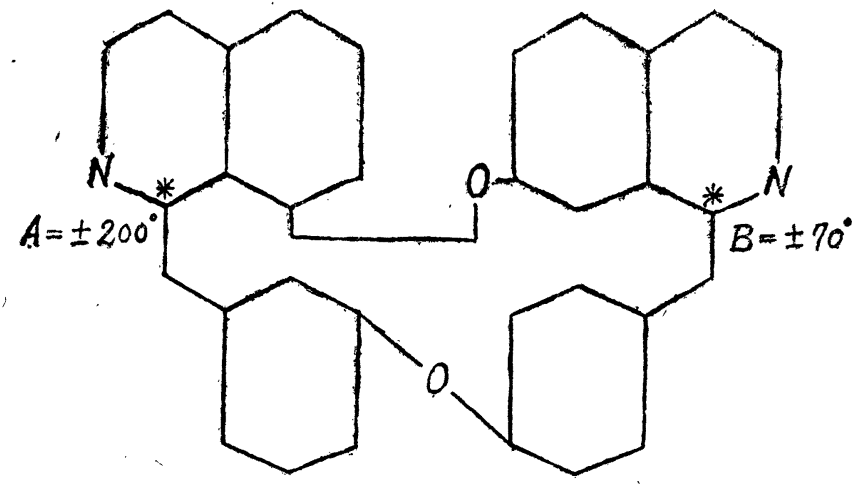

\begin{tabular}{|c|c|c|}
\hline$+A+B$ & $\begin{array}{r}\text { デントリン } \\
{[\alpha]_{D}=+263.1^{\circ}}\end{array}$ & $\begin{array}{c}\text { オキシアカンチン } \\
{[\alpha]_{D}=+279^{\circ}} \\
\text { 七ドロエピステファ } \\
\end{array}$ \\
\hline$+A-B$ & $\begin{array}{l}\text { イソテトランドリン } \\
{[\alpha]_{D}=+146^{\circ}}\end{array}$ & ヒドロエピステフ \\
\hline$-A+B$ & & \\
\hline$-A-B$ & $\begin{array}{l}フ_{ \pm} ア ン チ ン \\
{[\alpha]_{D}=-278^{\circ}}\end{array}$ & \\
\hline
\end{tabular}

偖植物體內でノルエビステファニン (XI) よりノル・オキシアカンチンへの還元反䧺に際しては著者の賽踰より明か な如く不齊合成の起る事は極めて明白である. そのよき例はテトランドリンとイソテトランドリンであつて, 兩者が 別々の植物より出現する事る斯樣な說によつてのみ合理的に說明出來るのである.

Bruchausen ${ }^{12}$ | はかつてテトランドリン型アルカロイドの旋光性を論じてその不齊の中心の一を $\pm 200^{\circ}$ とし, 他 を $\pm 70^{\circ}$ としたのである. エピステファニンの不齊の中心は一個で, その旋光度は略了前者の數值に一致するので, テ トランドリン型アルカロイドに於いては Bruchausen の說も成立するものと信ずる. 前報においてェビステフォニン の還元體はヒドロエビステフィニン-A 及-B の二種が出來る事を述べたのであるが, 前者はその不齊の中心が $(+,+)$

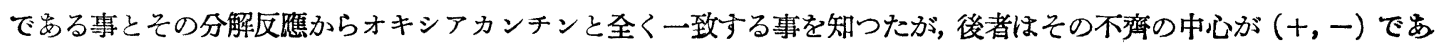

11) 返藤, 富田：藥誌 55, 914 (1935).

12) Bruchhausen, Oberembt u. Feldhaus : Ann 507, 144 (1933)。 
つて, そのホフマン分解に際してはヒドロエピステファニンーA よりのメチン (Fp 109-10) と同一のメチンが得られ るから，後者はテトランドリンに對するイッテトランドリンに對應すべき植物體內より未だ發見されない新アルカロ イドである．斯樣な說より考へれば近藤敉授が豫言されて居るフェアンチン $\left(\alpha_{D}=-270^{\circ}\right)$ に對する $\left(\alpha_{D}=-130^{\circ}\right)$ の アルカロイドも當然發見されてしかるべきものと思はれる.13)

終に臨み終始御懇篤なる御指導を賜つた恩師近藤先生に對し㖜心より感謝の意を表す. 又貴重なる標本を分與され

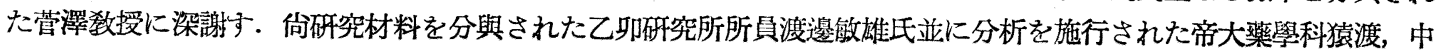
江の兩壤に御形豊申上げる.

,

\section{惯 驗 之 部}

1) ヒドロエピステフォニンーA の第一次エムデ分解(ヒドロメチンの生成)

メチルヒドロエピステフォニンーA ヨードメチラート $1.4 \mathrm{~g}$ をメタール水 $(3: 1)$ に溶解し, $1 \mathrm{~g}$ の确酸銀より製し た籃化銀と振盪してクロールメチラートとなし, 減壓で蒸發乾涸す. 残椬を $10 \mathrm{cc}$ に溶解して $5 \%$ ナトリウムアマ ルガム $30 \mathrm{~g}$ を加へて 10 時間輕く沸騰せしめる. 析出する油をベンジールに探り，5\% 稀硫酸で振湿すると白色の 硫酸監析出する.この沈澱を濾取して多量の熱湯に溶解し，一旦濾過後アンモニヤ水でアルカリ性となし，エーテル にて抽出す. エーテル溶液は炭酸加里で乾燥後溶媒を溜去し, 残渣に少量のメタノールを加へて放置すると脂肪樣光 濢を有する針狀結晶 $\left(\mathrm{Fp} 110-112^{\circ}\right)$ となる.

本品をオキシアカンチンより同樣の操作で得たヒドロメチン (Fp 110-2º $)$ ののと混融するに全く降下を認めな い(Fp $\left.110-2^{\circ}\right)$

分析 $\left(60^{\circ} 4\right.$ 時間乾燥)

試料 $4.482 \mathrm{mg}$ : $\mathrm{N}_{2} 0.167 \mathrm{cc}\left(27^{\circ}, 765 \mathrm{~mm}\right)$. $\mathrm{C}_{40} \mathrm{H}_{50} \mathrm{~N}_{2} \mathrm{O}_{6}$ 計算值 $\mathrm{N} 4.28$. 實驗值 $\mathrm{N} 4.20$.

2) ヒドロメチンヨードメチラート

ヒドロメチン $0.2 \mathrm{~g}$ をメタノールに溶解し， ヨードメチル $1 \mathrm{cc}$ を加へて水浴上に 1 時間加溫す. 溶媒を濃縮して 放置すると結晶析出する. 本品をメタノールより再結晶すると Z 240 - $2^{\circ}$ の稜杜狀結晶となる.オキシアカンチン より得たヒドロメチンョードメチラート $\left(\mathrm{Zp} 240-2^{\circ}\right)$ と混融すると全く降下を認めない $\left(\mathrm{Zp} 240-2^{\circ}\right)$.

分析 ( $90^{\circ} 4$ 時間乾燥)

試料 $3.578 \mathrm{mg}$ : $\mathrm{CO}_{2} 6.602 \mathrm{mg}, \mathrm{H}_{2} \mathrm{O} 1.950 \mathrm{mg}$.

$\mathrm{C}_{40} \mathrm{H}_{50} \mathrm{~N}_{2} \mathrm{O}_{6} \cdot 2 \mathrm{CH}_{3} \mathrm{~J} \cdot 4 \mathrm{H}_{2} \mathrm{O}$ 計算值 C $50.29, \mathrm{H}$ 6.38. 實驗值 C $50.32, \mathrm{H} 6.16$.

3) ヒドロメチン再結晶母液よりのヨードメチラート

ヒドロメチン再結晶母液にヨードメチルを加へて 1 時間水浴上に加熱す.メタノールを溜去すれば結晶析出す. 本 品は顥微鏡下で觀察すると明に混合物であるから,メタノールで再結晶を繰返すと難溶性のヨードメチラートとして 上記 Zp $240-2^{\circ}$ の稜杜狀結晶を得た.

再結晶母液はメタノールを數四に分けて濃縮し, 最後に析出する結晶を少量のメタノールで再結晶すると Z p 210 一 $1^{\circ}$ の針狀結晶となる.

本品もオキシアカンチンのヒドロメチン再結晶より得たメタノールに易溶のョードメチラート $\left(Z \mathrm{p} 209-10^{\circ}\right)$ と混 融すると降下を認めない $\left(Z \mathrm{p} 209-11^{\circ}\right)$.

合兩ヨードメチラートの中間に析出する部分を合してメタノールより再結晶したものは Späth の記載した Zp 230 一 $1^{\circ}$ を示す結晶である.

分析 ( $90^{\circ} 4$ 時間乾燥)

試料 $3.535 \mathrm{mg}$ : $\mathrm{CO}_{2} 6.646 \mathrm{mg}, \mathrm{H}_{2} \mathrm{O} 2.281 \mathrm{mg}$.

$\mathrm{C}_{40} \mathrm{H}_{50} \mathrm{~N}_{2} \mathrm{O}_{6} \cdot 2 \mathrm{CH}_{3} \mathrm{~J} \cdot 2 \mathrm{1} / 2 \mathrm{H}_{2} \mathrm{O}$ 計算値 C $51.28, \mathrm{H} 6.20$. 實驗値 C $51.27, \mathrm{H} 7.22$.

4) ヒドロエピステフォニンーA の第二次エムデ分解

(ハ・ヒドロデス・N·監基の生成)

ヒドロメチンョードメチラート (Zp 240-2 $\left.2^{\circ}\right) 0.4 \mathrm{~g}$ をメタノール水 $(3: 1)$ に溫時溶解して, 新製の監化銀と振温し てクッールメチラートとなし, 溶媒は減原で溜去して残渣を少量の水に溶解し, $5 \%$ ナトリウムアマルガム $25 \mathrm{~g}$ を加 へて直火で加熱する.十時間後析出する油をエーテルで抽出し, 稀硫酸及水で洗滌後枈酸加里で乾燥して溶媒を溜去

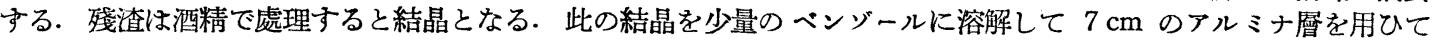
クロマトグラフを施行す，濾液を蒸發して殘椬を得なくなる汽展開する．全滤液を合して蒸發乾涸し，残椬を酒精よ

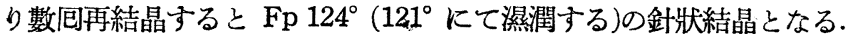

本品はオキシアカンチンより得た八・ヒドロデス・N 鹽基 $\left(F p 125^{\circ}\right)$ と混融も降下を認めない。

分析 ( $80^{\circ} 4$ 時間乾燥)

試料 $3.605 \mathrm{mg}$ : $\mathrm{CO}_{2} 10.012 \mathrm{mg}, \mathrm{H}_{2} \mathrm{O} 2.301 \mathrm{mg}$.

$\mathrm{C}_{32} \mathrm{H}_{40} \mathrm{O}_{6}$ 計算值 $\mathrm{C} 76.03, \mathrm{H}$ 7.04. 實驗值 C 75.74, H 7.14.

13) 近藤, 慶松： 薬誌 55, 894 (1935). 
5) メチン整基 (Fp 109-10 $)$ の接觸還元

メチン監基 $0.3 \mathrm{~g}$ を酒精に溶解し，パラヂウム炭 $0.3 \mathrm{~g}$ を加へて水素氣流中で振湯するに水素 $20.3 \mathrm{cc}$ (理論數 $19.5 \mathrm{cc}$ ) を吸收す. 溶媒は溜去し，残椬は少量のメタノールに溶解してョードメチル $1 \mathrm{cc}$ を加へて水浴上に加溫すると暫時 にしてョードメチラートの結晶析出する. 本結晶をメタノールより數四再結晶すると, Zp 242一 $3^{\circ}$ の白色稜桂狀結晶 となる. 本品は先に得たヒドロメチンョードメチラート $\left(Z \mathrm{p} 240-2^{\circ}\right)$ と混融すると全く融點の降下を認めない $(\mathrm{Zp}$ $\left.241-2^{\circ}\right)$.

分析 (90 4 時間㲦燥)

試料 $3.555 \mathrm{mg}$ : $\mathrm{CO}_{2} 6.495 \mathrm{mg}, \mathrm{H}_{2} \mathrm{O} 1.964 \mathrm{mg}$. $\mathrm{C}_{40} \mathrm{H}_{50} \mathrm{~N}_{2} \mathrm{O}_{6} \cdot 2 \mathrm{CH}_{3} \mathrm{~J} \cdot 4 \mathrm{H}_{2} \mathrm{O}$ 計算值 C $50.29, \mathrm{H} 6.38$. 實驗值 C $49.91, \mathrm{H} 6.18$.

6) オキシアカンチンの抽出及そのエムデ分解

a) オキシアカンチンの抽出

富士山麓地方に探集せる小集の根部及茎部 $(6.2 \mathrm{~kg})$ を細切して酒精で三回溫浸し，酒精を減壓で蒸發し得たェキ スに三倍量の水を加へて一旦濾過後不溶分は $2 \%$ 醋酸で更に抽出す．兩抽出液を合してアンモニヤアルカリ性とな し, 析出物をエーテルにて數可抽出す.エーテル抽出液は濃縮後 $2 \%$ 硫酸に監基を轉溶せしめ, 次に硫酸溶液に濃厚 ブロム加里液を沈澱の析出せざる迄加へて放置す．この沈澱を濾取して水より一度再結晶するブロム水素酸暨を結晶 性に得られる.この結晶を濾取して溫時に溶解し,アンモニャアルカリ性となしてエーテルにて抽出し, 更に $2 \%$ 硫 酸で䜿基を轉溶し，硫酸抽出液は艺硝を飽和せしめて放置すると硫酸監の結晶が析出する．この硫酸監を水に溶解し てアンモニヤアルカリ性となし，エーテルにて抽出し，エーテル溶液は炭酸加里で乾燥後濃縮すると針狀結晶が得ら れる. これを多量のエーテルより再結晶すると Fp 215一6 0 の結晶 $0.8 \mathrm{~g}$ を得た．本品はオキシアカンチン (Fp 215 一7) と混融するに全く融點の降下を認めない (Fp 215一6 $0^{\circ}$ ).

b) メチルオキシアカンチンヨードメチラート.

オキシアカンチンを少量のメタノールに溶解して，これにデアジメタンのエーテル溶萑を加へて一夜放置す。この エーテル溶液は稀苛性加里で洗淡後炭酸加里で乾燥する. エーテルを溜去した殘椬はメタノール溶液としてヨードメ チルを加へて一時間加溫す．メタノールを溜去した殘椬はアセトン・メタノールより再結晶すると Z $253-5^{3}$ の枝 状結晶となる．本品は先に得たメチルヒドロエピステフォンンーA ヨードメチラートと混融すると全く融點の降下を 認めない (Zp 251-4 $\left.{ }^{\circ}\right)$.

c) メチルオキシアカンチンヒドロメチン.

Späth の記载に從つて行ひ, ヒドロエピステファニンーA の場合の如く維溶性硫酸監を經て遊離したるヒドロメチン は Fp 110-2。 の結晶となる.

d) メチルオキシアカンチンーヒドロメチンーヨードメチラート.

上記七ドロメチンの結晶 $0.3 \mathrm{~g}$ をメタノール溶液となし, ヨードメチルと加溫して製す、メタノールより再結晶し たものは Zp 240一2 $2^{\circ}$ の稜杜狀結晶.

e) ヒドロメチン再結晶母液よりのヨードメチラート.

上記ヒドロメチンの再結晶母液にヨードメチルを作用せしめてョードメチラートとなし, 此處に得たヨードメチラ 一トはヒドロエピステフィニンの場合に於ける如くメタノール上り分劃結晶を行ふと難溶性ヨードメチラートとして Zp 239-42 $2^{\circ}$ の稜柱狀結晶を, 易溶性のヨードメチラートとして Zp 209-10 $10^{\circ}$ の針狀結晶が得られる.

向兩者の中間に析出する部分はメタノールょり再結晶すると混合物であつて Späth の記載に一致した (Zp 230 $\left.231^{\circ}\right)$.

f）オキシアカンチンの第二次エムデ分解(入・ヒドロ・デス・N・監基).

ヒドロメチンヨードメチラート (Zp 240-2.）を常法に反礁處理して Fp $125^{\circ}$ の結晶を得.

長崎醫科大學附屬藥學專門部

8. 安江政一：Piperidin よb Dimethylaminoisopentylchlorid の製造, 並に 其の 8-Aminochinolin 類との反應に就でヒノン誘導體の合成研究 III)*

ヒノリン及びアクリデンより誘導される合成マラリア治療劑は何れす側鎖に Diäthylaminoalkyl-基特に Diäthylaminoisopentyl-基を持つてるる. 此の Diäthylamino-基を Dimethylamino-基に置換した場合，効力を低下する事 は Magidson 等1)が 6-Methoxy-8-(8-diäthylaminopropyl)-aminochinolin に就てのみ實驗して結論してるるが

* 8-Aminochinolin との反應迄昭和 18 年 4 月藥學會總會學術講演會に於て發表せり. 前報本誌 62, 520 (昭和 17).

1) O. Ju. Magidson und M.O. Bobyschew : Chem. Zentr. 1939, I, 4952. . 